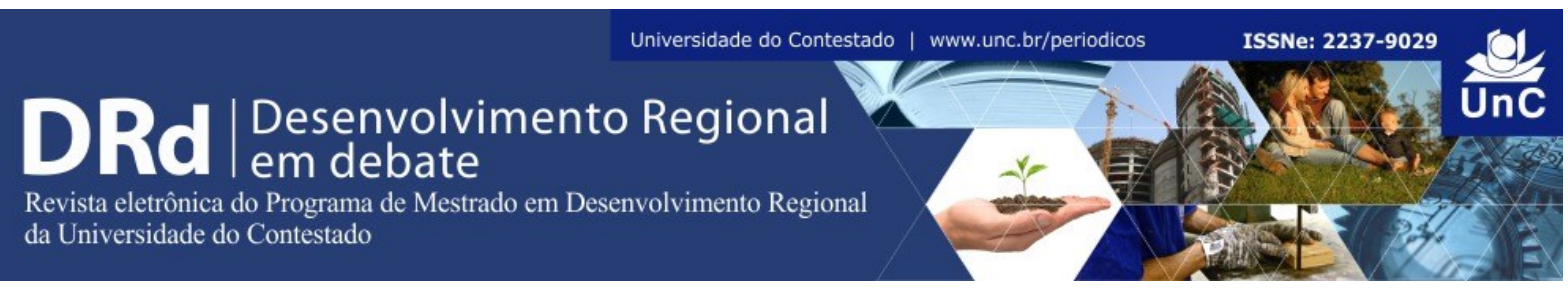

\title{
A PERCEPÇÃO DE FAMÍLIAS RURAIS SOBRE OS EFEITOS DO PROGRAMA
} LUZ PARA TODOS

\author{
Lívia Aladim Matosinhos ${ }^{1}$ \\ Marco Aurélio Marques Ferreira ${ }^{2}$ \\ Ana Paula Teixeira de Campos ${ }^{3}$ \\ Mateus Pereira Lavorato ${ }^{4}$
}

\section{RESUMO}

Criado em 2003, o Programa Luz para Todos (PLT) objetiva, com o combate à exclusão energética, impulsionar o desenvolvimento local e aumentar a qualidade de vida de seus beneficiários. Considerando os benefícios sociais e econômicos relacionados à eletrificação rural e as proposições teóricas de Ranganathan (1993), o presente trabalho busca, por meio de um estudo de caso comparativo, investigar a percepção de famílias beneficiadas pelo PLT acerca do acesso e uso da energia elétrica. Em geral, observa-se que as, predominantemente positivas, percepções dos entrevistados quanto ao desenvolvimento se diferenciam de acordo o município de residência, corroborando assim as expectativas teóricas.

Palavras-chave: Eletrificação rural. Programa Luz para Todos. Percepção. Desenvolvimento.

\section{THE PERCEPTION OF RURAL FAMILIES ABOUT THE EFFECTS OF THE LUZ PARA TODOS PROGRAM}

\begin{abstract}
Created in 2003, the Luz para Todos program (PLT) aims to boost local development and increase the quality of life of its beneficiaries via energy exclusion elimination. Considering the social and economic benefits related to rural electrification and the theoretical propositions of Ranganathan (1993), the present article seeks, by means of a comparative case study, to investigate the perception of families benefited by the PLT about the access and use of electricity. In general, it is observed that the, predominantly positive, perceptions of the

\footnotetext{
${ }^{1}$ Doutoranda em Administração pela Universidade Federal de Viçosa (UFV). Mestra em Extensão Rural pela Universidade Federal de Viçosa (UFV). Viçosa. Minas Gerais. Brasil. E-mail: aladimlivia@gmail.com. ORCID: https://orcid.org/0000-0001-6402-1079

${ }^{2}$ Doutor em Economia Aplicada pela Universidade Federal de Viçosa (UFV). Professor do Departamento de Administração e Contabilidade (DAD) da Universidade Federal de Viçosa (UFV). Viçosa. Minas Gerais. Brasil. E-mail: marcoufv1@gmail.com. ORCID: https://orcid.org/0000-0002-9538-1699

${ }^{3}$ Pós-doutoranda no DAD/UFV. Universidade Federal de Viçosa (UFV). Doutora em Ciências Sociais em Desenvolvimento, Agricultura e Sociedade pela Universidade Federal Rural do Rio de Janeiro (UFRRJ). Universidade Federal de Viçosa (UFV). Viçosa. Minas Gerais. Brasil. E-mail: aptcampos@gmail.com. ORCID: https://orcid.org/0000-0002-3527-2730.

${ }^{4}$ Doutorando em Economia Aplicada pela Universidade Federal de Viçosa (UFV). Mestre em Economia Aplicada pela Universidade Federal de Viçosa (UFV). Viçosa. Minas Gerais. Brasil. E-mail: lavoratomateus@gmail.com. ORCID: https://orcid.org/0000-0002-4425-3718.
}

DRd - Desenvolvimento Regional em debate (ISSNe 2237-9029)

v. 9 , p. 604-624, 2019. 
interviewees on development differ according to the municipality of residence, thus corroborating the theoretical expectations.

Keywords: Rural electrification. Luz para Todos program. Perception. Development.

\section{INTRODUÇÃO}

O meio rural brasileiro possui uma demanda histórica por eletrificação. O modelo de desenvolvimento adotado no País durante grande parte do século XX pode ser apontado como um dos fatores determinantes para a exclusão elétrica de significativa parte da população rural brasileira. Atento a esta situação, e compreendendo o papel do Estado como provedor de bens essenciais à população, o Governo Federal lançou, em 2003, a maior iniciativa pública de combate à exclusão elétrica da história do Brasil, o Programa Nacional de Universalização do Acesso e Uso da Energia Elétrica, popularmente conhecido como "Luz para Todos" (PLT). Como principal objetivo do PLT, estipulou-se que o acesso à energia elétrica atuasse como um vetor de desenvolvimento socioeconômico das comunidades atendidas, auxiliando no aumento da renda familiar e, por conseguinte, na redução da pobreza no meio rural brasileiro (MME, 2009).

Em um país extenso e diversificado como o Brasil, as demandas sociais e econômicas de sua população podem se dar de diferentes formas, de acordo com as diferentes carências de suas regiões. No caso da eletrificação rural, por exemplo, a necessidade de acesso a este serviço pode se dar por diferentes motivos em diferentes locais do País. É nesse sentido que Ranganathan (1993) expôs, em seu trabalho, quatro diferentes papeis que a eletrificação rural poderia exercer de acordo com as demandas relacionadas a diferentes perfis socioeconômicos da população, quais sejam: commodity (mercadoria) para consumo; input (insumo) produtivo; infraestrutura de desenvolvimento; e bem essencial. Muito embora a supracitada pesquisa seja pautada em uma construção teórica, acredita-se que resultados empíricos possam apontar para outras direções, como, inclusive, a sobreposição de mais de um tipo de demanda para uma mesma localidade geográfica.

Matosinhos, Ferreira e Campos (2017), seguindo o raciocínio de Ranganathan (1993), elaboraram uma análise para Minas Gerais, na qual procuraram dividir os municípios do referido estado em termos de variáveis socioeconômicas relacionadas ao processo de eletrificação rural. Os grupos formados foram caracterizados de acordo com a semelhança entre a situação socioeconômica dos municípios que os compuseram e relacionados aos papéis identificados por Ranganathan. Para tanto, os autores utilizaram dados do Censo Demográfico do ano 2000, tendo em vista que o lançamento do PLT se deu em 2003.

Pautando-se no mencionado trabalho, a presente pesquisa pretende, com a análise de dados primários coletados em municípios da mesorregião da Zona da Mata de Minas Gerais, investigar a existência de diferentes percepções entre os beneficiários dos municípios analisados quanto à eletrificação rural e às melhorias sociais e econômicas a ela relacionadas. Além disso, busca-se também analisar os desdobramentos do acesso à energia elétrica na qualidade de vida e nas atividades produtivas das famílias pesquisadas e a relação do PLT com outras políticas sociais já acessadas nestes locais.

DRd - Desenvolvimento Regional em debate (ISSNe 2237-9029) 
O restante desse artigo é dividido como segue. Discorre-se, na próxima seção, sobre os benefícios relacionados ao processo de eletrificação rural e como eles podem contribuir para o desenvolvimento da população atendida. Na terceira seção são apresentadas as ferramentas metodológicas utilizadas na presente pesquisa. Já na quarta seção, os municípios analisados são caracterizados em termos da realidade de suas zonas rurais. A quinta seção compreende os resultados encontrados e sua discussão. Por fim, as principais conclusões são apresentadas na sexta seção.

\section{FUNDAMENTAÇÃO TEÓRICA}

Muito se discute acerca da definição do termo desenvolvimento. Com o passar do tempo, foi-se abandonando a perspectiva puramente economicista, voltada para a industrialização e os avanços tecnológicos que engendravam ganhos econômicos e, consequentemente, um incremento no Produto Interno Bruto (PIB). Estabeleceu-se, em seu lugar, uma visão socioeconômica pautada em uma maior preocupação quanto ao fator humano e toda sua diversidade, da qual emerge a necessidade de uma interdisciplinaridade entre as vertentes técnica, tecnológica e social que englobam as intervenções estatais voltadas para a sociedade (CERNEA, 1995).

Seguindo este pensamento, estudos sobre o desenvolvimento rural brasileiro procuram, desde a década de 1980, retratar uma visão mais ampla do que aquela voltada apenas para o desenvolvimento agrícola - que buscou beneficiar produtores mais capitalizados, exportadores de commodities e as elites agrárias. Ao contrário, destaque passou a ser dado aos movimentos em prol da agricultura familiar e seus atores, apontados como principais afetados pelas implicações advindas do intenso processo de modernização agrícola do Brasil, que lutam - há décadas - pelo direito de participarem ativamente na elaboração de políticas voltadas para seu desenvolvimento (GRISA; SCHNEIDER, 2014).

Desprendendo-se da ideia de desenvolvimento rural atrelado ao agrícola, as atuais políticas públicas voltadas para o desenvolvimento rural devem direcionar seu foco a três atributos fundamentais do rural brasileiro: produção econômica e de bens públicos de caráter ambiental; reprodução de modos de vidas diferenciados; e a relação com a natureza, valorizando a multifuncionalidade ${ }^{5}$ do meio rural. Deve-se buscar, deste modo, a superação da antiga visão dicotômica acerca da relação rural e urbano, no intuito de se destacar a existente interdependência entre estes meios (BRASIL, 2010).

Tal mudança de perspectiva rumo à uma visão mais social ocorreu concorrentemente ao advento do receituário neodesenvolvimentista, o qual passou a ser aplicado à política econômica brasileira a partir do início da década de 2000 com a chegada do Partido dos Trabalhadores (PT) ao poder. Baseando-se nas construções teóricas cepalinas e se presentando

\footnotetext{
${ }^{5} \mathrm{O}$ termo multifuncional ou, de acordo com van der Ploeg et al. (2000), multifacetado, se refere ao fato de que as atividades econômicas realizadas no meio rural não necessitam, necessariamente, estar relacionadas somente à produção agropecuária. Há, neste meio, uma gama de atividades relacionadas à conservação de paisagens e valores naturais como o agro turismo, a produção orgânica e de produtos regionais específicos de alta qualidade que podem garantir uma diversificação das atividades rurais e uma grande geração de renda para o meio rural.
}

DRd - Desenvolvimento Regional em debate (ISSNe 2237-9029) 
como uma contraposição à proposta neoliberal, o neodesenvolvimentismo admite que, para se ter uma economia de mercado forte, faz-se necessária uma expressiva atuação e regulação estatal (MOURA, 2015). A redução das desigualdades sociais, sob a ótica neodesenvolvimentista, passa, dentre outros pontos, pela promoção da equidade social (CASTELO, 2010).

Com isso, o conceito de desenvolvimento se torna mais amplo. As ações desenvolvimentistas - principalmente as de origem governamental - passam a considerar os interesses da sociedade como um todo e a valorizar particularidades locais, dando prioridade à qualidade e durabilidade da vida, além da acumulação financeira e do crescimento econômico. Assim surge a concepção de desenvolvimento local, que, sob a ótica de Gehlen (2004), é definido como "as dinâmicas social, econômica, política e cultural num território demarcado por especificidades que induzem mudanças qualitativas naquele espaço". Ainda segundo este autor, as políticas públicas induzem fortalecimento do desenvolvimento local, partindo-se de diagnósticos capazes de identificar pontos focais para a formulação de uma proposta global de desenvolvimento, de modo que as políticas públicas de desenvolvimento se fundam com o social, buscando valorizar as diferenças e conquistar qualidade de vida e ambientes sustentáveis.

Ao se discutir sobre o processo de eletrificação rural através de políticas governamentais, destacam-se a redução da pobreza e o alcance do desenvolvimento social e econômico por parte das famílias beneficiadas como os principais objetivos destas ações. Tais objetivos são estabelecidos tendo em vista as possíveis melhorias proporcionadas pelo acesso e uso da energia elétrica no cotidiano da população rural, as quais impactariam positivamente suas condições sociais e econômicas. Quanto à redução da pobreza, considerando-a como o baixo alcance de condições sociais básicas (como nutrição, educação e saúde), Kanagawa e Nakata (2008) consideram o acesso à energia como uma das muitas maneiras de se promover oportunidades de atingir um patamar básico de condições essenciais.

Sobre as melhorias possivelmente proporcionadas a famílias rurais pela eletrificação, diversos são os aspectos apresentados pela literatura em que estas podem ocorrer. Bernard (2010), ao analisar a literatura relacionada à avaliação de impacto da eletrificação no meio rural, expõe que a energia elétrica atua como facilitadora do desenvolvimento daqueles que a possuem por potencialmente proporcionar melhores resultados econômicos, sociais e ambientais, dentre outros. Quanto aos benefícios relacionados ao bem-estar destas famílias, estes podem ser percebidos no ambiente doméstico, na saúde dos seus integrantes, no melhor aproveitamento do tempo (que proporciona maior conforto para esta população), na educação e nas atividades produtivas praticadas por famílias rurais (IEG, 2008).

Pode-se exaltar, na literatura específica, que o acesso e uso da energia elétrica seriam capazes de induzir o desenvolvimento social e econômico de famílias rurais (e.g., CECELSKI; GLATT, 1982; TORERO, 2015; BHATTACHARYYA, 2006; DINKELMAN, 2011). Além disso, estabelecendo-se uma relação entre o entendimento de desenvolvimento a partir da percepção individual e a atuação dos programas de eletrificação rural como facilitadores do desenvolvimento de famílias rurais, pressupõe-se que, para diferentes indivíduos, as melhorias percebidas em diferentes localidades após o recebimento do benefício proveniente destas políticas podem indicar diferentes percepções de desenvolvimento social e econômico.

DRd - Desenvolvimento Regional em debate (ISSNe 2237-9029) 


\section{METODOLOGIA}

Buscando destacar eventuais diferenças na percepção da população atendida pelo PLT quanto a seus possíveis benefícios e levando em conta as diversas necessidades socioeconômicas encontradas em regiões de Minas Gerais, optou-se por construir um estudo de caso comparativo com uma aplicação relativista em municípios do referido estado. Um estudo de caso consiste na investigação de casos específicos, bem delimitados e contextualizados para a geração de informações acerca do objeto de estudo (VENTURA, 2007) e se caracteriza como comparativo quando, utilizando o mesmo material, compara descrições alternativas ou explicações de duas ou mais situações (YIN, 2013). A aplicação relativista, para Yin (2013), ocorre quando um conjunto semelhante de episódios de um mesmo caso se repete sob a perspectiva de diferentes participantes e apresenta múltiplas realidades.

Como instrumento utilizado para a execução da pesquisa, optou-se pelo questionário semiestruturado, que, combinando perguntas fechadas e abertas, oferece aos entrevistados a oportunidade de dissertar acerca do assunto proposto (BONI; QUARESMA, 2005) e, com isso, permite captar uma maior riqueza de detalhes sobre a temática analisada. Para a aplicação deste estudo, foram escolhidos três municípios mineiros, de acordo com os seguintes critérios: (i) pertencerem aos diferentes grupos (Baixo, Médio-baixo e Médio-alto) formados por Matosinhos, Ferreira e Campos (2017); (ii) possuírem no mínimo 45\% de sua população residindo no meio rural; (iii) possuírem um percentual relevante de eletrificação de domicílios rurais entre os anos 2000 e 2010, de acordo com dados censitários, em comparação com os demais municípios; e (iv) estarem localizados na mesorregião da Zona da Mata. Diante de tais condições, foram selecionados os municípios de Brás Pires, Paula Cândido e Porto Firme.

Foram acionados, em cada um dos municípios escolhidos, os escritórios locais da Empresa de Assistência Técnica e Extensão Rural de Minas Gerais (Emater-MG) e as Secretarias Municipais de Agricultura. Por meio deste contato, possibilitou-se a obtenção dos cadastros de moradores interessados no benefício concedido pelo PLT, elaborados previamente e/ou durante a ação do programa nos escritórios locais da Emater-MG. Ademais, houve o auxílio dos representantes destas instituições - Secretário de Agricultura de Brás Pires, Secretário do escritório da Emater-MG de Porto Firme e Secretário de Agricultura de Paula Cândido - na elaboração do itinerário das entrevistas, bem como na apresentação da equipe aos entrevistados. Ressalta-se aqui a extrema importância do apoio destes indivíduos na concretização desta pesquisa, visto que, no meio rural, a identificação de endereços de domicílios torna-se praticamente impossível sem o auxílio de pessoas que conheçam o local e, em muitos casos, moradores deste meio podem se recusar a conceder entrevistas a desconhecidos.

Para cada um dos municípios analisados foram conseguidos os contatos de, aproximadamente, 100 moradores que se cadastraram para o recebimento da energia elétrica por meio do PLT. Deve-se destacar que o número relativamente pequeno de cadastros é justificado pela ausência da disponibilidade/divulgação de registros oficiais do PLT pelas entidades governamentais, inclusive o próprio Ministério de Minas e Energia. Os cadastros obtidos junto aos escritórios locais da Emater-MG foram resultados de dedicação pessoal dos técnicos e funcionários, muitos deles contratados/empossados após o período de cadastramento dos potenciais beneficiários do PLT. O número de cadastros também não retrata o total de

DRd - Desenvolvimento Regional em debate (ISSNe 2237-9029) 
beneficiários desta ação, tratando-se apenas de um levantamento prévio dos interessados no benefício realizado com o objetivo de facilitar as ações iniciais das concessionárias encarregadas da execução do programa. Por fim, destaca-se que a amostragem foi feita por conveniência, devido à dificuldade de acesso a determinados domicílios.

\subsection{SOBRE OS MUNICÍPIOS ESTUDADOS}

Conforme exposto anteriormente, optou-se pela escolha de três municípios que integrassem os três diferentes grupos identificados por Matosinhos, Ferreira e Campos (2017), no intuito de se confirmar as conclusões formuladas por esses autores. Estando localizadas na mesma mesorregião geográfica, percebeu-se relativa similaridade entre as cidades estudadas quanto suas principais atividades agropecuárias. Destacaram-se o cultivo de milho, feijão e café, bem como a criação de gado para leite. Além disso, há uma grande incidência de plantações de eucalipto no meio rural dos três locais. Os dados apresentados abaixo foram extraídos dos Relatórios de Atividades Anuais (RAA) de 2016, gentilmente cedidos pelos escritórios locais da Emater-MG. Os municípios são apresentados em ordem crescente de desempenho socioeconômico, conforme definido por Matosinhos, Ferreira e Campos (2017).

O município de Brás Pires, integrante do grupo responsável pelos índices socioeconômicos mais baixos da análise, possuía 4.637 habitantes, dos quais 52\% residiam no meio rural. No ano $2000,62 \%$ de seus domicílios rurais possuíam acesso à energia elétrica, enquanto esta parcela aumentou em 33,7 pontos percentuais em 2010. O PIB municipal, para o ano de 2016, foi de 32,27 milhões de reais, tendo a agropecuária contribuído com 16,26\% desse valor. Foram registrados, para este mesmo ano, 661 agricultores familiares no município, que ocupa a posição de número 520 no ranking estadual de Índice de Desenvolvimento Humano (IDH).

Paula Cândido, por seu turno, ocupa a posição de número 549 no ranking mineiro de IDH. Aproximadamente 18,8\% do PIB municipal de 77,8 milhões de reais foram gerados por atividades agropecuárias. Em uma população rural de 4.335 habitantes, a qual compreendia $46,76 \%$ da população do município, foram registrados 1.800 agricultores familiares. A taxa de eletrificação rural evoluiu de $77 \%$ em 2000 para $99 \%$ no ano de 2010 , perfazendo um aumento de 22 pontos percentuais. Nesse município, além dos produtos agropecuários previamente citados, também foi registrada uma alta incidência do cultivo de frutas, como goiaba e maracujá.

Já no município de Porto Firme, cuja população rural representava 53,62\% do total de habitantes, foram registrados 2.100 agricultores familiares, o que equivale a quase $5 \%$ da população municipal. Ocupando a posição de número 605 no ranking estadual de IDH, o município alcançou, em 2016, um PIB de 74,4 milhões de reais. Deste valor, 16,34\% foram gerados pela agropecuária. Em 2010 a taxa de eletrificação rural atingiu $99 \%$ após ter se elevado em aproximadamente 16 pontos percentuais desde o ano 2000.

A relação da teoria de Ranganathan (1993) com a realidade apresentada pelos meios rurais dos municípios estudados é apresentada na Tabela 1. Em Brás Pires, componente do grupo Baixo, o advento da eletrificação rural atuaria como um bem essencial. Aliada a benefícios governamentais de transferência e geração de renda, a eletricidade induziria

DRd - Desenvolvimento Regional em debate (ISSNe 2237-9029) 
melhores condições básicas de vida à população beneficiada por meio do acesso a água potável, luz elétrica e bens de consumo, como geladeira e televisão, melhorando a higiene e a saúde dentro dos domicílios, além de facilitar as tarefas diárias dentro e fora de casa.

No município de Paula Cândido, integrante do grupo Médio-baixo, a energia elétrica atuaria principalmente como um insumo produtivo, capaz de trazer benefícios para as atividades agropecuárias lá praticadas e, consequentemente, maiores ganhos financeiros para os agricultores - principalmente para aqueles participantes de programas de incentivo à produção familiar. Por fim, para a cidade de Porto Firme, representante do grupo Médio-alto, cujos índices referentes à qualidade de vida e atividade produtiva eram relativamente mais altos, percebe-se que o acesso à energia elétrica poderia ser enxergado com uma commodity utilizada a nível domiciliar. Isto é, um bem de consumo final que não interferiria nos níveis sociais e produtivos de seus beneficiários.

Tabela 1 - Relação entre municípios analisados e a teoria de Ranganathan (1993).

\begin{tabular}{lccc}
\hline & Brás Pires & Paula Cândido & Porto Firme \\
\hline Grupo & Baixo & Médio-baixo & Médio-alto \\
Condições sociais* & Precárias & Razoáveis & Razoáveis \\
Condições econômicas $^{*}$ & Precárias & Precárias & Razoáveis \\
Papel da eletrificação rural & Bem essencial & Insumo produtivo & Commodity \\
\hline
\end{tabular}

Nota: * Antes do processo de eletrificação rural.

Fonte: Matosinhos, Ferreira e Campos (2017).

\section{RESULTADOS}

Foi aplicado um total de 51 questionários, igualmente distribuídos entre os locais analisados, isto é, 17 entrevistas por município. Foram percorridos, somente dentro das comunidades rurais dos três municípios pesquisados, pouco mais de 400 quilômetros entre os meses de julho a setembro de 2017. A duração das entrevistas variou entre 30 e 60 minutos por domicílio visitado. A pesquisa foi conduzida mediante aprovação do Comitê de Ética em Pesquisa com Seres Humanos (CEP) da Universidade Federal de Viçosa (UFV) e todos os entrevistados assinaram um termo de consentimento livre e esclarecido.

A distribuição dos respondentes entre as principais variáveis descritivas é apresentada na Tabela 2. Prevaleceu, dentre os respondentes, o gênero masculino nos municípios de Brás Pires (56,3\%) e Porto Firme (62,5\%). Em Paula Cândido, por outro lado, 52,9\% das entrevistas foram concedidas por respondentes do gênero feminino. Este fato pode estar diretamente ligado à questão profissional, já que nos dois primeiros municípios, a maioria dos homens exercia sua atividade geradora de renda (ligada à agricultura familiar) no próprio domicílio e ficava por conta de recepcionar a equipe de pesquisa. Já em Paula Cândido, notou-se um grande percentual de homens, chefes de família, que trabalhavam como diaristas em propriedades vizinhas $(35,3 \%)$, ou em atividades não agropecuárias com carteira assinada $(11,7 \%)$, e, nestes casos, apenas as mulheres se encontravam no domicílio no momento das entrevistas.

DRd - Desenvolvimento Regional em debate (ISSNe 2237-9029) 
Percebeu-se, na cidade de Brás Pires, um significativo número de respondentes com os menores índices de estudo: $81,3 \%$ da amostra não havia completado o ensino fundamental, corroborando as estatísticas apresentadas por Matosinhos, Ferreira e Campos (2017) para o grupo ao qual este município pertence. No caso de Paula Cândido, mesmo apresentando o maior percentual $(52,9 \%)$ para esse município, a situação de ensino fundamental incompleto se mostrou a menor da pesquisa, dividindo o resultado das repostas, principalmente, com ensino fundamental completo e ensino médio completo ou incompleto. Este resultado reflete proximamente a situação geral do grupo Médio-Baixo - considerado o mais heterogêneo por Matosinhos, Ferreira e Campos (2017). As expectativas para Porto Firme apontavam para um maior índice de escolaridade da população, pois o município pertence ao grupo com as melhores características sociais e econômicas. Constatou-se, todavia, que quase $82 \%$ de seus respondentes não completaram o ensino fundamental.

Quanto à principal atividade de sustento das famílias entrevistadas, apenas em Brás Pires a agropecuária não se destacou expressivamente, representando metade das respostas. Tal fato é explicado pela grande quantidade de domicílios que possuía como maior fonte de renda a aposentadoria rural $^{6}$ de pelo menos um de seus integrantes. Nos demais municípios a agropecuária representou a atividade geradora de renda mais citada entre as famílias, tendo maior destaque - 87,5\% - em Porto Firme. Ao responderem sobre a renda total mensal domiciliar, os entrevistados confirmaram o inicialmente esperado para cada grupo: $62,5 \%$ dos respondentes de Brás Pires arrecadava uma quantia inferior a um salário mínimo, 52,9\% da amostra de Paula Cândido alegou possuir uma renda total de um a dois salários mínimos e, em Porto Firme, $62,6 \%$ da população informou receber entre um e dois $(31,3 \%)$ e de dois a três $(31,3 \%)$ salários mínimos. Cabe aqui destacar que, na maioria dos casos, o número de moradores dependentes dessas rendas variava entre 3 a 5 por domicílio. Logo, mesmo naquele município que apresentou maiores ganhos mensais, nota-se uma renda per capita relativamente baixa para os moradores de seu meio rural.

\footnotetext{
${ }^{6}$ Refere-se aqui, e em todo o trabalho, ao Benefício de Prestação continuada da Lei Orgânica da Assistência Social (BPC/Loas), que concede, sem a necessidade de prévia contribuição previdenciária, um benefício assistencial de um salário mínimo a idosos acima de 65 anos ou portadores de deficiência cuja renda familiar não ultrapasse 1/4 de salário mínimo (Brasil, 1995).
} 
Tabela 2 - Distribuição dos respondentes entre as principais variáveis descritivas

\begin{tabular}{|c|c|c|c|}
\hline & Brás Pires & Paula Cândido & Porto Firme \\
\hline \multicolumn{4}{|l|}{ Gênero } \\
\hline Masculino & 56,30 & 47,10 & 62,50 \\
\hline Feminino & 43,70 & 52,90 & 37,50 \\
\hline \multicolumn{4}{|l|}{ Escolaridade } \\
\hline Fundamental & 87,50 & 82,35 & 93,75 \\
\hline Médio & 06,25 & 17,65 & 06,25 \\
\hline Superior & 06,25 & 00,00 & 00,00 \\
\hline \multicolumn{4}{|l|}{ Estado civil } \\
\hline Solteiro & 12,50 & 05,90 & 00,00 \\
\hline Casado & 75,00 & 88,20 & 93,75 \\
\hline Separado & 00,00 & 05,90 & 06,25 \\
\hline Viúvo & 12,50 & 00,00 & 00,00 \\
\hline \multicolumn{4}{|c|}{ Principal fonte de sustento } \\
\hline Agropecuária & 50,00 & 76,50 & 87,50 \\
\hline Outras fontes & 50,00 & 23,50 & 12,50 \\
\hline \multicolumn{4}{|c|}{ Auxílio governamental } \\
\hline Sim & 81,25 & 76,50 & 87,50 \\
\hline Não & 18,75 & 23,50 & 12,50 \\
\hline \multicolumn{4}{|c|}{ Política governamental } \\
\hline Sim & 12,50 & 70,60 & 68,75 \\
\hline Não & 87,50 & 29,40 & 31,25 \\
\hline \multicolumn{4}{|l|}{ Renda domiciliar } \\
\hline Até $1 \mathrm{SM}$ & 62,50 & 35,30 & 25,00 \\
\hline De 1 a 2 SM & 18,75 & 52,90 & 31,25 \\
\hline De 2 a 3 SM & 06,25 & 05,90 & 31,25 \\
\hline De 3 a 4 SM & 06,25 & 00,00 & 06,25 \\
\hline De 4 a $5 \mathrm{SM}$ & 00,00 & 00,00 & 06,25 \\
\hline Mais de 5 SM & 06,25 & 05,90 & 00,00 \\
\hline
\end{tabular}

Fonte: Resultados da pesquisa.

Percebeu-se, em todos os municípios, que boa parte dos respondentes recebia algum auxílio governamental de transferência de renda, sendo este auxílio proveniente do programa Bolsa Família ${ }^{7}$ e/ou de aposentadoria rural. Esta proporção foi de $81 \%$ em Brás Pires, 70,6\% em Paula Cândido e 68,8\% em Porto Firme. Para essas famílias, a aquisição de bens de consumo duráveis movidos à energia elétrica após o benefício do PLT só foi possível devido ao fato de serem também beneficiárias desses programas de transferência de renda. Esses resultados reafirmam a necessidade de uma complementariedade entre políticas de transferência de renda e o PLT para que seus beneficiários atinjam melhores níveis de qualidade de vida, conforme exaltado anteriormente por Ruijven, Schers e Vuuren (2012).

Não só as famílias que recebem transferência de renda do governo afirmaram terem adquirido/ganhado bens de consumo duráveis após serem beneficiadas pelo PLT. Todos os respondentes da pesquisa informaram a posse de geladeira, televisão, chuveiro elétrico e algum tipo de eletrodoméstico portátil. Além disso, mais de $80 \%$ dos respondentes nos três municípios possuíam tanquinho ou máquina de lavar roupas. Percebeu-se claramente na fala dos moradores, uníssonos ao responderem que a existência de energia elétrica influenciava positivamente nos afazeres domésticos de seus domicílios, a importância da energia elétrica e

${ }^{7}$ O Bolsa Família é um programa governamental de transferência condicional de renda voltado ao combate da pobreza e da desigualdade no Brasil. Mais informações em $<$ http://mds.gov.br/assuntos/ bolsa-familia $>$.

DRd - Desenvolvimento Regional em debate (ISSNe 2237-9029) 
do uso destes aparelhos para a promoção do conforto, da facilitação das tarefas diárias e da comunicação com tudo o que se encontra além do rural. A fala da Entrevistada 4, do município de Paula Cândido, ilustra essa situação:

Agora dá para guardar os alimentos por mais tempo com geladeira, e o trabalho fica mais leve, porque a gente tem liquidificador, ferro e bomba (d'água), que traz a água cá para dentro de casa. $\mathrm{Na}$ "panha' ${ }^{8}$ do café, todo mundo fica fora de casa o dia todo e quando chega, deixa a roupa lavando na máquina. Com a luz dá para cozinhar a noite, e até para descansar um pouco vendo TV (Entrevistada 4, 34 anos, agricultora de Paula Cândido).

Além deste relato, destaca-se também o da Entrevistada 12, relacionado à higiene e saúde: "A casa ficou bem melhor e mais fácil de limpar depois que veio a energia. Mas o melhor mesmo foi não precisar ir lá no hospital quando meu tio, que é doente, dava crise (de asma), porque agora a gente faz a nebulização dele aqui mesmo" (Entrevistada 12, 55 anos, agricultora de Porto Firme). Em poucos casos, alguns entrevistados relataram pequenas mudanças no convívio dentro de suas casas, devido à utilização de televisão ou internet para entretenimento individual. Com a inserção de novos meios de comunicação no cotidiano familiar, a intensidade das relações interpessoais pode ter diminuído, embora nenhum entrevistado tenha exaltado esta questão.

Quanto às políticas de governo relacionadas à produção agropecuária, percebeu-se uma taxa de adesão expressivamente baixa nos municípios de Brás Pires, onde $12 \%$ dos entrevistados alegaram já ter contratado crédito pelo Programa Nacional de Fortalecimento da Agricultura Familiar (Pronaf), e Paula Cândido, onde 17,6\% dos respondentes contrataram crédito junto ao Pronaf ou forneceram alimentos ao Programa Nacional de Alimentação Escolar (PNAE) ou ao Programa de Aquisição de Alimentos (PAA). Situação contrária foi percebida em Porto Firme, onde $75 \%$ dos respondentes afirmou tomar ou já ter tomado algum crédito junto ao Pronaf. Percebeu-se, principalmente em Brás Pires, a baixa efetividade do apoio técnico e a falta de conhecimento sobre a contratação do crédito como os possíveis motivos da baixa adesão ao crédito rural. Isso vai ao encontro das constatações de Uchiyama (2009), que afirma que a ausência de capacitação e infraestrutura em empreendimentos rurais familiares pode fazer com que agricultores não possuam recursos o suficiente para a quitação de créditos.

Pode-se, ainda, estabelecer uma relação entre a adesão aos programas anteriormente citados e possíveis aumentos nos ganhos provenientes das atividades geradoras de renda. Em Brás Pires, $25 \%$ dos respondentes declararam ter percebido algum aumento em sua renda após a chegada da energia elétrica proveniente do PLT. Em Paula Cândido (41\%) e Porto Firme $(81,3 \%)$ esse número foi mais elevado. Para todos os municípios este aumento percebido se deu através da aquisição de equipamentos movidos à energia elétrica que otimizam ou tornam a produção agropecuária menos pesada, não sendo registrado nenhum novo empreendimento não-agrícola, relacionado à cultura, artesanato ou turismo rural. A afirmação do Entrevistado 7, de Paula Cândido ilustra esta constatação:

Todas as coisas que eu comprei para usar aqui em casa quando chegou a luz ajudam muito na criação dos animais, a manter as plantações e a economizar. Aí, a gente tem recurso para ganhar um dinheirinho a mais e para ter uma alimentação mais saudável dentro de casa (Entrevistado 7, 29 anos, agricultor e assistente de produção de Paula Cândido).

${ }^{8}$ Nome informal dado ao processo de colheita manual de café. 
A grande maioria dos entrevistados respondeu positivamente sobre a aquisição de equipamentos voltados à produção agropecuária após a obtenção do serviço de energia elétrica - 68,8\% em Brás Pires, 76,5\% em Paula Cândido e 87,5\% em Porto Firme. Dentre esses, percebeu-se unanimidade quanto à obtenção de bombas d'água, que além de facilitarem a manutenção de plantações e criações, são de suma importância para o abastecimento do domicílio e, consequentemente, para a saúde e higiene de seus habitantes. Comprova-se, deste modo, as ideias sugeridas por Di Lascio e Barreto (2009), Oliveira (2001), Reiche, Covarrubias e Martinot (2000), Ribeiro e Santos (1994), de que a melhoria na captação da água apresenta impactos positivos sobre a qualidade de vida e o trabalho da população rural. Destacaram-se também a compra de motores utilizados em moinhos, picadeiras e ensiladeiras, bem como aquisição do aparato necessário para irrigação, ordenha e resfriamento de leite e derivados (tanque e freezer), e processamento do café. Nas Figuras 1 e 2, têm-se exemplos de novos bens adquiridos por beneficiários do programa após o acesso à energia elétrica.

Figura 1 - Agricultor de Paula Cândido e sua máquina de secar café.

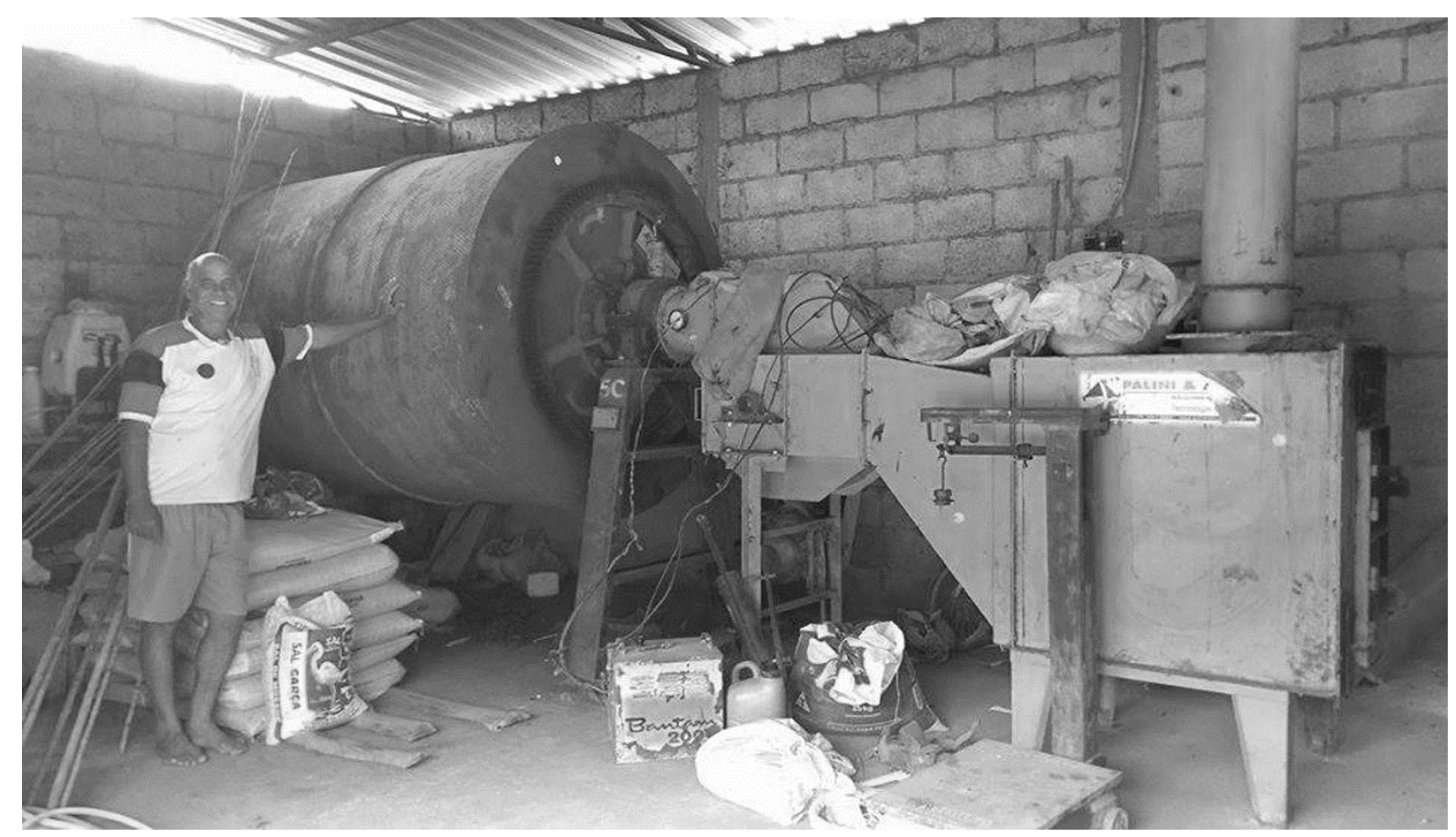

Fonte: Acervo dos autores (2017). 
Figura 2 - Moinho movido a motor elétrico construído por um agricultor de Paula Cândido.

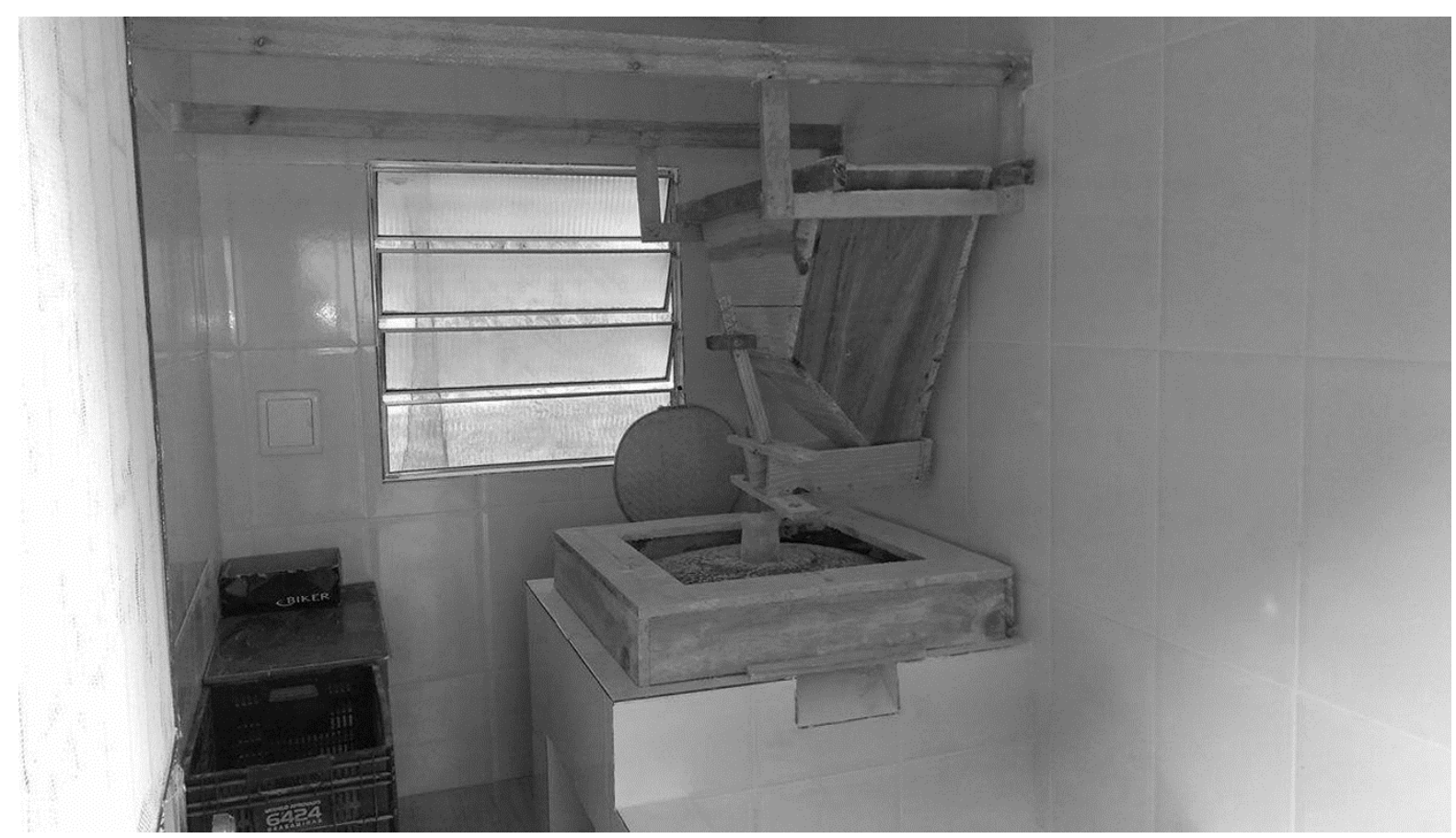

Fonte: Acervo dos autores (2017).

Foram analisadas também as impressões dos entrevistados quanto à influência do acesso à energia elétrica sobre os estudos fora do período escolar. Todos aqueles que afirmaram existir um ou mais estudantes em seus domicílios - 43,8\% em Brás Pires, 70,6\% em Paula Cândido e $53 \%$ em Porto Firme - confirmaram a observância de impactos positivos da eletrificação sobre o desempenho escolar. Maior destaque foi dado à possibilidade de se aproveitar o período noturno, geralmente após a chegada da escola, para a realização de tarefas, pesquisas e estudos para provas, dada a melhor qualidade da iluminação dentro do domicílio. Outros aspectos apontados foram a possibilidade de obtenção de informações via canais educativos de televisão, celular e computador (este último item é utilizado na escola ou em casa, nos poucos casos onde entrevistados afirmaram possuí-lo), como apresentado na Figura 3.

Ademais, houve uma percepção dos moradores quanto a um aspecto particular da zona rural: a distância entre os domicílios e as escolas. Devido ao fato de que a maioria dos estudantes deve se preparar com antecedência para esperar o ônibus escolar, com as facilidades proporcionadas pela eletrificação rural, este preparo se torna mais fácil e rápido, conforme explica o Entrevistado 3, de Paula Cândido:

Ficou bem melhor para poder acordar cedo quando tem horário de verão, que fica mais escuro. Melhorou bastante também para organizar o material, o lanche, e para dar banho quente nas crianças antes de ir para a escola. Dá até para elas acordarem um pouquinho mais tarde (Entrevistado 3, 37 anos, agricultor de Paula Cândido).

Quanto a uma possível relação entre a falta de energia no meio rural e a migração de seus habitantes para o meio urbano, indagou-se aos respondentes se a ausência deste bem essencial foi determinante para a mudança de pessoas próximas para outras regiões. Aqui, também foi observada certa heterogeneidade quanto às respostas obtidas nos diferentes 
municípios. Em geral, cerca de $82 \%$ dos respondentes dos municípios representantes dos grupos Médio-alto e Médio-baixo confirmaram essa relação. Por outro lado, mesmo sendo maioria, apenas $56 \%$ dos respondentes de Brás Pires seguiu este pensamento. Esta situação também foi observada quando se indagou sobre as chances de permanência no meio rural, caso a energia elétrica ainda fosse de difícil acesso: enquanto em Porto Firme e Paula Cândido registrou-se afirmações de que as chances de permanência seriam baixas ou muito baixas, para Brás Pires as respostas concentravam-se mais entre chances altas de permanência e indiferença quanto à relação investigada.

Figura 3 - Estudante de Porto Firme utilizando seu computador em casa, no meio rural.

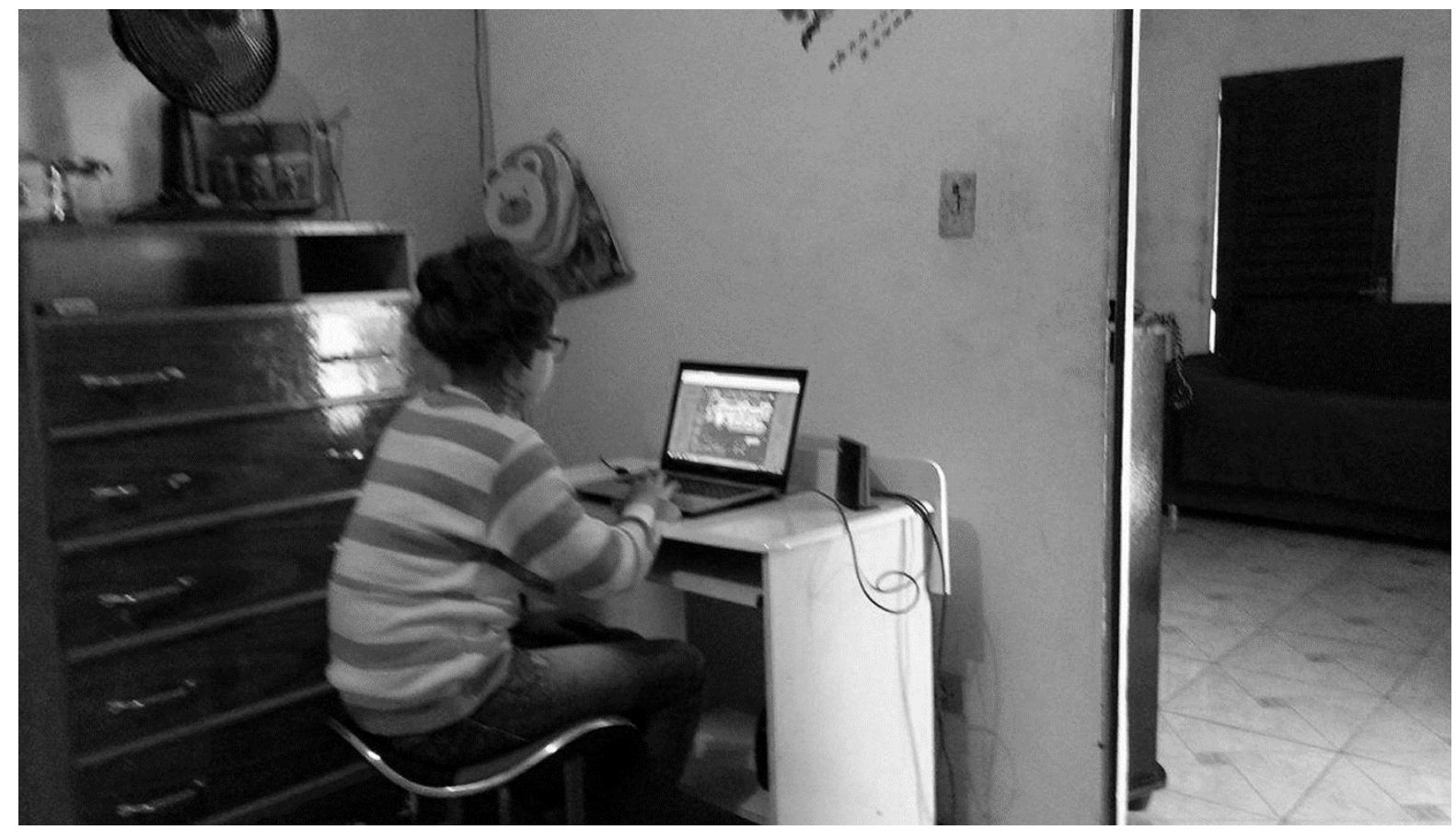

Fonte: Acervo dos autores (2017).

Como justificativa para tais reações, os habitantes deste município apontaram um principal motivo condicionante para a permanência e evasão do campo: a falta de condições financeiras para suportar o custo de vida no meio urbano - considerado mais alto comparado ao do meio rural. Retratando o que Mancuso e Ramiro (2010) definiram como "balanço permanência-migração", mesmo enfrentando condições relativamente adversas, como falta de infraestrutura e acesso a bens e serviços essenciais, devido ao baixo poder aquisitivo, famílias instaladas no meio rural não consideram a mudança para o meio urbano, pois perderiam sua autonomia e um certo nível de qualidade de vida. Neste ponto da pesquisa, acentuam-se as evidências de que municípios do grupo Baixo, de fato, não possuem as condições necessárias e suficientes para que moradores do meio rural consigam, por si só, alcançar melhores níveis de qualidade de vida.

Na Figura 4 é feita uma síntese do contraponto observado entre as percepções dos entrevistados dos diferentes grupos analisados quanto à permanência no meio rural dada a falta de acesso à energia elétrica, exaltando os principais motivos para as diferenças observadas. 
Por fim, os entrevistados foram induzidos a recordarem sobre como eram suas vidas antes de terem acesso à energia elétrica em seus domicílios e a expressarem como se sentem diante deste benefício. Independente do município em que viviam, os entrevistados responderam a estas perguntas de maneira unânime. A vida no meio rural antes da chegada da energia elétrica foi relacionada pelos respondentes à dificuldade e tristeza, muitos até indo um pouco mais além, mencionando também o sofrimento. Como principal motivo pelo qual esta relação foi estabelecida, tem-se a forma em que os trabalhos - tanto relacionados à atividade agropecuária, quanto às atividades domésticas - eram executados: através de processos manuais, considerados excessivamente pesados, demorados e cansativos.

Figura 4 - Contraponto entre grupos: permanência no meio rural.

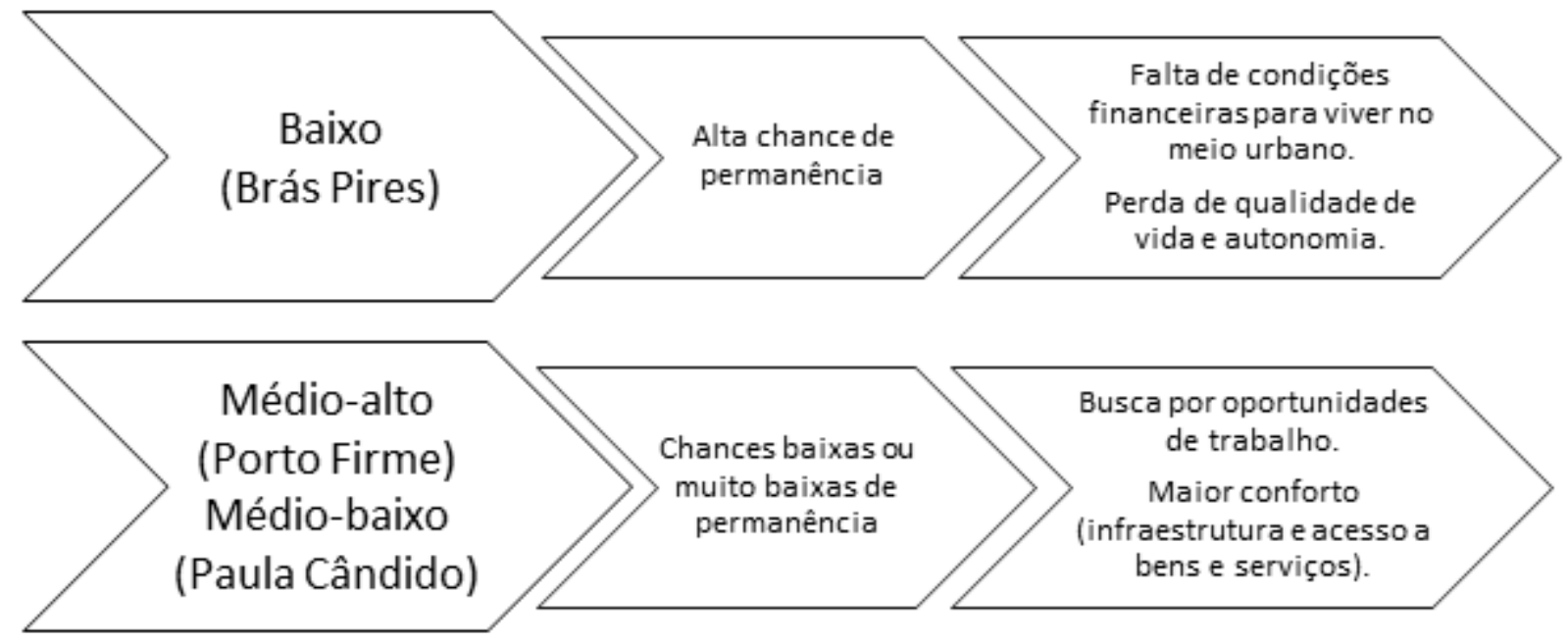

Fonte: Elaborada pelos autores com base nos resultados da pesquisa.

Além disso, também foram apontados outros motivos, como a falta de luz e todas as limitações decorrentes deste fato, principalmente durante o período noturno: os problemas respiratórios provenientes do uso de lamparinas, lampiões e lenha; o sentimento de insegurança devido ao fato de residirem em locais afastados com precariedade de iluminação; a falta de comunicação, informação e entretenimento nos horários de descanso; o desconforto de se tomar banhos frios, ou "banhos de caneca", caso quisessem tomar banho quente; e a falta de água em suas propriedades, o que os obrigava a buscá-la em lugares muito afastados de seus domicílios. Destacam-se aqui algumas falas que retratam algumas das situações mencionadas: "Dava angústia. Não podia ter convívio com os outros e nem podia fazer as coisas de casa de noite, tinha que usar a lamparina" (Entrevistado 1, 85 anos, aposentado de Porto Firme); "Tinha muita dificuldade na hora de lavar a roupa. Roupa de cama então, era um sufoco! Quando lavava coberta, precisava de três pessoas para torcer e colocar pra secar" (Entrevistada 14, 32 anos, dona de casa de Paula Cândido); "Era bastante sofrida, para as coisas mais urgentes a gente dependia dos outros e tinha vergonha disso. Em casa tinha que dormir cedo, que a gente não tinha nem televisão, e ainda tomava banho de bacia mesmo" (Entrevistada 1, 38 anos, agricultora de Paula Cândido).

Já quanto ao significado do acesso à energia elétrica em seus domicílios, muitos dos entrevistados demonstraram a essencialidade deste serviço, reforçando que, atualmente, não conseguem - e nem querem - desenvolver atividades essenciais ao seu cotidiano sem a

DRd - Desenvolvimento Regional em debate (ISSNe 2237-9029) 
utilização da energia elétrica. Segundo eles, a partir do benefício concedido pelo programa, todos os integrantes de suas famílias observaram melhorias em seus afazeres e na qualidade de suas vidas: "A energia te dá uma despesa a mais, mas o que ela te dá de conforto já compensa tudo. A gente paga a conta com satisfação" (Entrevistado 10, 32 anos, agricultor de Paula Cândido); "(A luz) É tudo para a gente. Ninguém vive sem; ficar sem energia dificulta tudo. Quando falta, fica até sem água, e a gente liga pra Cemig9 até voltar" (Entrevistada 12, 27 anos, agricultora de Brás Pires); "Melhorou muito, melhor coisa que aconteceu na roça para mim! A gente se sente muito bem, dá para ter vários aparelhos e fazer as coisas de noite. Hoje, sem luz você não tem nada" (Entrevistada 16, 42 anos, agricultora de Porto Firme).

Vale destacar que em momento algum desta pesquisa houve registro de relatos contra as tarifas cobradas pelas concessionárias pelo uso da energia elétrica. Destaca-se como principal reclamação, registrada com maior intensidade no município de Brás Pires, um desapontamento com a carga ${ }^{10}$ (monofásica) disponibilizada pelo PLT, que, em muitos casos, não é suficiente para o funcionamento de máquinas voltadas à melhoria da produção agropecuária, como motores e resfriadores. Tal aspecto, mesmo que indiretamente, poderia influenciar o acesso a políticas públicas relacionadas à produção agropecuária, visto que os produtores poderiam se sentir desestimulados. Deste modo, muitos dos entrevistados que conseguem adquirir tais equipamentos, com ou sem amparo financeiro do Governo, se sentem prejudicados pela limitação de explorar todo o potencial desses maquinários. Esta situação não foi observada nos demais municípios e também não foram encontrados registros referentes à carga distribuída ou alguma regra de padronização referente a este quesito - pelas diferentes concessionárias nas diferentes localidades beneficiadas.

\subsection{OUTROS FENÔMENOS OBSERVADOS}

A decisão de se aplicar um questionário semiestruturado foi tomada com o objetivo de, além das situações já definidas anteriormente à pesquisa, se ter a possibilidade de captar, na fala dos participantes, aspectos adicionais percebidos pelos beneficiários do programa quanto à temática investigada. Através dos relatos feitos não só nas respostas às questões abertas, mas, também, como complemento às questões fechadas, pode-se destacar mudanças nos casos onde moradores já possuíam energia elétrica devido ao uso de geradores e de ligações compartilhadas com vizinhos que já a possuíam. Registrou-se também a ocorrência de casos de outros moradores que, mesmo solicitando o serviço, não foram beneficiados pelo programa. Todos os fenômenos aqui citados foram observados nos três municípios onde se deu a pesquisa.

Alguns moradores, cuja renda apresentava-se mais alta, e que, em sua maioria, já residiam no mesmo lugar há mais tempo, optaram pelo uso do gerador de energia em seus domicílios anteriormente ao início da ação do PLT. De acordo com seus relatos, os geradores supriam suas necessidades relacionadas ao uso da energia elétrica, porém, os gastos com

\footnotetext{
${ }^{9}$ Refere-se à Companhia Energética de Minas Gerais, a concessionária responsável pela distribuição de energia elétrica nos municípios de Brás Pires e Porto Firme. O município de Paula Cândido, por sua vez, é atendido pela empresa Energisa, antiga Companhia Força e Luz Cataguazes-Leopoldina (CFLCL).

${ }^{10}$ Há a possibilidade de aumento da carga elétrica disponibilizada no domicílio, porém, é necessária participação financeira do interessado.
}

DRd - Desenvolvimento Regional em debate (ISSNe 2237-9029)

v. 9, p. 604-624, 2019. 
combustível para o funcionamento destes aparelhos eram altos e impediam seus proprietários de adquirir novos equipamentos que aumentariam o consumo de energia de seus domicílios. Tem-se como maior exemplo deste caso, o relato do Entrevistado 7, da cidade de Brás Pires, retratado na Figura 5, que conseguiu otimizar o processo de distribuição de seus produtos:

Aqui em casa eu faço queijo com uma parte do leite que eu tiro. Quando tinha gerador, eu fazia e levava para a cidade porque não tinha como guardar na geladeira e ia ficar muito caro usar um freezer. Hoje eu já posso ter ele aqui, que não pesa na conta. Aí eu junto mais queijo para não ir à cidade todo dia. Porque cansa, né? (Entrevistado 7 , 43 anos, agricultor de Brás Pires).

Além disso, moradores que utilizavam o gerador em suas casas alegaram sentir falta das recorrentes visitas que recebiam de vizinhos que aproveitavam a existência de luz elétrica para se reunirem e conversarem durante a noite, ou assistir televisão. O Entrevistado 9, de Brás Pires, confessou sentir saudades da época anterior ao PLT em sua fala:

Ficar sem luz era ruim. Na verdade, era ruim nada. Eu tenho um acordeão, sabe? Aí chegava de tarde e muitos vinham para eu tocar uma música para eles, e a gente dançava a noite toda! Tinha muita gente, tinha forró todo sábado! Piorou também que os vizinhos vinham aqui em casa para assistir televisão também. Tinha dia que vinha umas quinze pessoas aqui em casa para ver televisão. Agora não precisa mais (Entrevistado 9, 86 anos, aposentado de Brás Pires).

Este depoimento reflete uma percepção predominante entre os entrevistados de idade mais avançada. Mesmo contentes diante dos benefícios alcançados pela eletrificação, eles apontam para a existência de um efeito colateral negativo: a alteração das relações interpessoais no meio rural. Nota-se um certo saudosismo quanto às relações mais estreitas e de caráter idílico, caracterizadas pelo contato mais intenso entre habitantes de uma mesma comunidade que, segundo os entrevistados, tornaram-se mais escassas diante das oportunidades de entretenimento possibilitadas pelo acesso à energia elétrica nos domicílios rurais.

Figura 5 - Agricultor de Brás Pires e o freezer utilizado na conservação de leite e queijo.

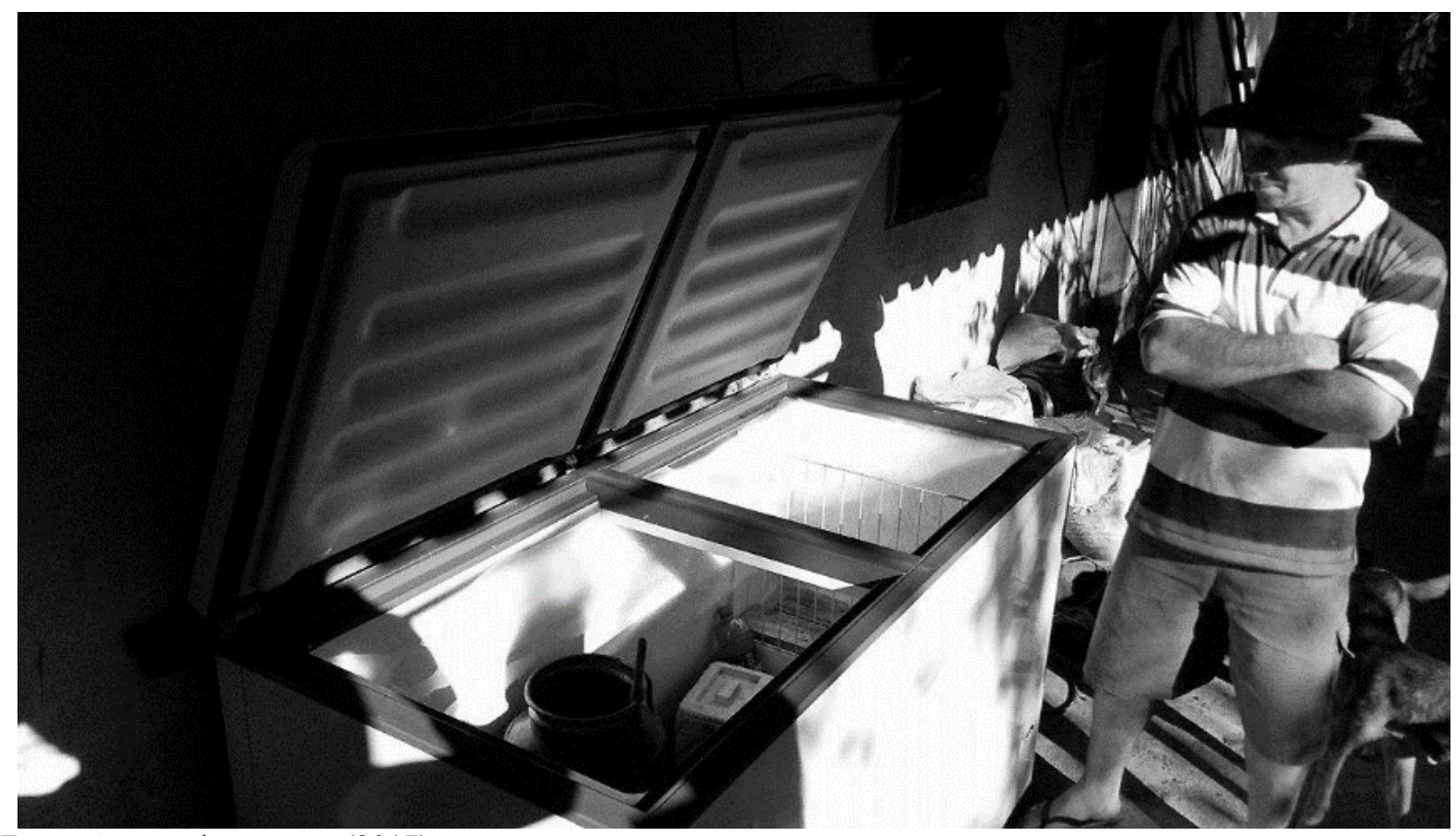

Fonte: Acervo dos autores (2017).

DRd - Desenvolvimento Regional em debate (ISSNe 2237-9029) 
Sobre o compartilhamento de energia elétrica entre domicílios rurais, identificou-se uma sensação de independência daqueles que posteriormente foram beneficiados pelo PLT. Para muitas famílias que não conseguiam arcar com os valores exigidos pelas concessionárias para efetuarem a instalação da estrutura necessária para o acesso à energia elétrica, era oferecida, por vizinhos que já a possuíam, a possibilidade de uma extensão dos fios condutores de energia até seu terreno. O mesmo também acontecia em propriedades onde filhos de moradores que possuíam energia elétrica construíam suas residências no mesmo terreno e utilizavam da estrutura que ali já se encontrava.

Para o primeiro caso, a principal reclamação quanto a esta situação residia na forma que a conta mensal era dividida, sendo a parcela a eles destinada mais alta do que o que pretendiam pagar e até mesmo da que pagam atualmente, diretamente à concessionária. Já aqueles que dividiam a energia com familiares, não se sentiam satisfeitos com a relação de dependência criada com os pais. Pode-se apontar, para ambos os casos, a prevalência de uma relação implícita de poder, onde, até certo ponto, os indivíduos que "emprestavam" a energia podiam exercer controle acerca do acesso e uso da eletricidade por parte dos indivíduos "ajudados".

Por fim, foram muitas as narrativas de beneficiários sobre parentes, vizinhos ou conhecidos, também residentes no meio rural, que ainda não haviam sido contemplados pelo PLT. De acordo com os relatos feitos, em alguns casos, pessoas que se cadastraram nos períodos destinados a esta ação não receberam o benefício em seu domicílio e tampouco foram informados sobre os motivos da não ocorrência de atendimento.

\section{CONCLUSÕES}

A utilização de um estudo de caso comparativo para a verificação das hipóteses inicialmente levantadas neste trabalho corroborou os resultados encontrados por Matosinhos, Ferreira e Campos (2017), evidenciando que, de fato, existem diferenças na capacidade da energia elétrica de influenciar a vida da população dos diferentes municípios estudados, dadas as diferentes realidades sociais e econômicas observadas. Vale ressaltar, contudo, a presença de distintas realidades dentro de um mesmo município, o que indica o caráter heterogêneo das famílias rurais mesmo em níveis geográficos menores.

No tangente à verificação dos papéis exercidos pela eletrificação rural nos municípios analisados, dadas as expectativas iniciais relacionadas aos diferentes grupos aos quais estes municípios foram alocados, percebe-se que os resultados inicialmente esperados foram confirmados para significativa parte dos domicílios investigados nos municípios de Brás Pires (grupo Baixo) e Paula Cândido (grupo Médio-baixo). No primeiro caso, em que se esperava que o acesso à energia elétrica atuaria como um bem essencial, trazendo melhores condições básicas de qualidade de vida, notou-se que, com a chegada da energia e utilizando-se de recursos financeiros provenientes de transferências governamentais, as famílias entrevistadas que, no geral, apresentavam baixos rendimentos financeiros e, consequentemente, baixo poder aquisitivo - atingiram melhorias em seus níveis de qualidade de vida, relacionadas à saúde, higiene e bem-estar. Ainda para estas famílias, não se percebeu, contudo, melhorias relacionadas às atividades agropecuárias por elas praticadas. Já para Paula Cândido, cidade componente do grupo Médio-baixo, cuja expectativa se fundava na atuação da energia elétrica

DRd - Desenvolvimento Regional em debate (ISSNe 2237-9029) 
como insumo produtivo para as atividades agropecuárias já praticadas pelas famílias que ali residiam, foram percebidas pelos respondentes da pesquisa maiores oportunidades de investimento em maquinário agrícola - possibilitado, em grande parte, pela tomada de crédito subsidiado - que, além de otimizar o trabalho dos agricultores, elevou a produtividade agrícola, possibilitando um aumento de suas rendas totais.

Quanto à hipótese de que para a cidade de Porto Firme a energia elétrica teria a função de commodity como principal papel para as famílias beneficiadas, conclui-se que tal situação só pode ser confirmada em famílias compostas por pessoas idosas e/ou aposentadas, cujos filhos já possuem famílias constituídas e/ou apresentam independência financeira. Nestes casos, realmente, a energia elétrica possibilitou apenas um maior conforto dentro de seus domicílios, não influenciando na agricultura familiar (quando ainda praticada), dado que seus integrantes possivelmente não mais necessitam de ganhos provenientes de atividades agropecuárias para se manter. Porém, para aquela parcela da população considerada economicamente ativa, percebeu-se, além do papel de commodity, a atuação da eletrificação rural como insumo produtivo, pois, assim como para Paula Cândido, agricultores familiares deste município tiveram a oportunidade de, com a obtenção da energia elétrica, tecnificar o seu modo de produção, aumentando assim a produtividade e seus ganhos financeiros. Com isso, conclui-se que entre os grupos Médio-baixo e Médio-alto, a maior diferença percebida reside no fato que no primeiro dar-se-ia prioridade para as melhorias nas atividades agropecuárias já praticadas ao passo que no segundo caso seria possível, ao mesmo tempo, além do investimento de melhorias na agropecuária, o alcance de um maior conforto dentro de seus domicílios.

Sobre o desenvolvimento socioeconômico, pode-se concluir que o mesmo foi percebido por todos os entrevistados após o PLT ter possibilitado o acesso à energia elétrica. Em seus relatos, habitantes dos três municípios destacaram melhorias percebidas em suas vidas, relacionando-as a questões sociais e/ou econômicas. Para os beneficiários de Brás Pires, o desenvolvimento percebido se deu na possibilidade de acesso a itens imprescindíveis para o modo de vida contemporâneo e que garantem um nível básico de qualidade de vida, antes não atingido. No caso dos municípios de Paula Cândido e Porto Firme, além da elevação de condições sociais, as famílias relataram que graças às melhorias percebidas após a chegada da energia elétrica, houve elevação de suas rendas. Percebe-se, nestes dois casos, indícios de desenvolvimento social e econômico para famílias beneficiadas pelo PLT.

É preciso destacar também os casos onde os entrevistados já possuíam energia elétrica em seu domicílio, seja por meio de geradores ou pelo compartilhamento com vizinhos e/ou familiares. Além da melhoria percebida quanto à qualidade da energia disponibilizada por meio do programa, se comparada àquela que possuíam anteriormente, grande destaque é dado para a independência adquirida após o benefício proporcionado pelo programa. Por um lado, aqueles que possuíam geradores dependiam de um estoque de combustível que limitava o potencial de utilização da energia elétrica em seus domicílios. Por outro, aquelas famílias que obtinham acesso à energia de modo compartilhado arcavam, em geral, com custos mais elevados do que o seu próprio consumo, além de estarem sujeitas às precariedades das ligações elétricas não profissionais.

Como principais contribuições dos resultados aqui encontrados, têm-se a indicação de que para as famílias beneficiárias analisadas, o acesso à energia elétrica - via PLT - contribuiu, de fato, para a melhoria de suas condições de vida, indo ao encontro do objetivo traçado pelo Governo quando da elaboração do Programa. Ressalta-se, porém, que os resultados observados 
poderiam ser potencializados caso outras políticas governamentais atuassem de forma complementar à eletrificação rural. Neste sentido, a assistência técnica pode ser enxergada como um mecanismo fundamental, não só para a promoção de políticas públicas em geral, mas também para a melhoria dos resultados associados ao acesso da população rural à política de eletrificação. Foi observado, inclusive, que essa comunhão é mais incipiente nos locais em que poderiam ser observadas mudanças mais expressivas.

Por fim, vale destacar que observações de campo apontaram para a existência de famílias ainda sem acesso à energia elétrica, mesmo com o expressivo atendimento do PLT nos municípios analisados. Essa situação pode ser vista como indicação de que, para que se atinja efetivamente a universalização do acesso e uso da energia elétrica, é necessária a continuidade da atuação governamental. De fato, essa conclusão está em consonância com a ação do Governo Federal que, em maio de 2018, modificou o prazo de finalização do programa de 2018 para 2022.

\section{REFERÊNCIAS}

BERNARD, T. Impact Analysis of Rural Electrification Projects in Sub-Saharan Africa. The World Bank Research Observer, v. 27, n. 1, p. 1-19, 2010.

BHATTACHARYYA, S. C. Energy access problem of the poor in India: Is rural electrification a remedy? Energy Policy, v. 34, n. 18, p. 3387-3397, 2006.

BONI, V.; QUARESMA, S. J. Aprendendo a entrevistar: como fazer entrevistas em Ciências Sociais. Em Tese, v. 2, n. 1, p. 68-80, 2005.

BRASIL. Instituto Brasileiro de Geografia e Estatística. Censo Demográfico, 2010. Disponível em: <http://www.ibge.gov.br>. Acesso em: 27 jun. 2017.

BRASIL. Presidência da República. Casa Civil. Decreto n. 1.744, de 08 de dezembro de 1995. Regulamenta o Benefício de Prestação Continuada, devido à pessoa portadora de deficiência e ao idoso, de que trata a Lei 8.742, de 7 de dezembro de 1993 e dá outras providências. Brasília, 1995.

CASTELO, R. Encruzilhadas da América Latina no século XXI. Rio de Janeiro: Pão e Rosas, 2010.

CECELSKI, E.; GLATT, S. The role of rural electrification in development. Washington, DC: Resources for the Future, 1982.

CERNEA, M. M. Primero la gente: Variables Sociológicas en el Desarrollo Rural. Cidade do México: Banco Mundial, 1995.

DI LASCIO, M. A.; FAGUNDES-BARRETO, E. J. Energia e desenvolvimento sustentável para a Amazônia rural brasileira: eletrificação de comunidades isoladas. Brasília:

Ministério de Minas e Energia, 2009.

DRd - Desenvolvimento Regional em debate (ISSNe 2237-9029) 
DINKELMAN, T. The effects of rural electrification on employment: New evidence from South Africa. The American Economic Review, v. 101, n. 7, p. 3078-3108, 2011.

GEHLEN, I. Políticas públicas e desenvolvimento social rural. São Paulo em Perspectiva, v. 18, n. 2, p. 95-103, 2004.

GRISA, C.; SCHNEIDER, S. Três gerações de políticas públicas para a agricultura familiar e formas de interação entre sociedade e estado no Brasil. Revista de Economia e Sociologia Rural, v. 52, n. s1, p. 125-146, 2014.

INDEPENDENT EVALUATION GROUP. The Welfare Impact of Rural Electrification: A Reassessment of the Costs and Benefits. Washington, DC: World Bank, 2008.

MANCUSO, M. I. R.; RAMIRO, P. A. De volta ao campo: estratégias para se viver a pobreza. Revista Espaço de Diálogo e Desconexão, v. 2, n. 2, 2010.

MATOSINHOS, L. A.; FERREIRA, M. A. M.; DE CAMPOS, A. P. T. Typifying the Demand for Rural Electrification: An Empirical Analysis for the Mesoregions of Minas Gerais State, Brazil. International Journal of Energy Economics and Policy, v. 7, n. 5, p. 227-234, 2017.

MINISTÉRIO DE MINAS E ENERGIA. Programa Luz Para Todos: Um marco histórico 10 milhões de brasileiros saíram da escuridão. Brasília: Secretaria de Energia Elétrica, 2009.

MOURA, E. J. L. O neodesenvolvimentismo no Brasil e os impactos às políticas sociais. In: JORNADA INTERNACIONAL POLÍTICAS PÚBLICAS, 7., 2015, São Luís. Anais... São Luís: UFMA, 2015.

OLIVEIRA, L. C. Perspectivas para a eletrificação rural no novo cenário econômicoinstitucional do setor elétrico brasileiro. Rio de Janeiro, Dissertação (Mestrado em Ciências em Planejamento Energético) - UFRJ, 2001.

RANGANATHAN, V. Rural electrification revisited. Energy Policy, v. 21, n. 2, p. 142-151, 1993.

REICHE, K.; COVARRUBIAS, A.; MARTINOT, E. Expanding electricity access to remote areas: off-grid rural electrification in developing countries. In: ISHERWOOD, G. (Ed). WorldPower 2000. Londres: Isherwood Prod, 2000.

RIBEIRO, F. S.; SANTOS, J. F. M. Política de eletrificação rural: superando dilemas institucionais. Revista do BNDES, v. 1, n. 2, p. 131-152, 1994.

RUIJVEN, B. J.; SCHERS, J.; VUUREN, D. P. Model-based scenarios for rural electrification in developing countries. Energy, v. 38, n. 1, p. 386-397, 2012.

TORERO, M. The Impact of Rural Electrification: Challenges and Ways Forward. Revue d'économie du développement, v. 23, p. 49-75, 2015. 
UCHIYAMA, L. L. Energia elétrica: Impactos socioeconômicos e as condições das famílias do espaço rural de Manaus. Manaus, Dissertação (Mestrado em Desenvolvimento Regional) UFAM, 2008.

VAN DER PLOEG, J. D. et al. Rural Development: From Practices and Policies towards Theory. Sociologia Ruralis, v. 40, n. 4, p. 391-408, 2000.

VENTURA, M. M. O estudo de caso como modalidade de pesquisa. Revista da SOCERJ, v. 20, n. 5, p. 383-386, 2007.

YIN, R. K. Case study research: Design and methods. Newbury Park: Sage Publications, 2013.

Artigo recebido em: 20/07/2019

Artigo aprovado em: 17/09/2019

Artigo publicado em: 19/09/2019 